\title{
Composition characterization and biological activity study of Thymbra spicata l. var. spicata essential oil
}

\author{
Nuraniye ERUYGUR ${ }^{1}$ (i), Umit M. KOCYIGIT ${ }^{2}$ (D), Mehmet ATAS ${ }^{3}$ (D), Ozge CEVIK ${ }^{4}$ (D) Faik \\ GÖKALP ${ }^{5 \text {, * (D), Parham TASLIMI }}{ }^{6}$ (D), Ilhami GULCIN ${ }^{7}$ (iD)
}

${ }^{1}$ Department of Pharmacognosy, Selcuk University Faculty of Pharmacy Konya / Turkey

${ }^{2}$ Vocational School of Health Services, Cumhuriyet University, Sivas / Turkey

${ }^{3}$ Department of Pharmaceutical microbiology, Cumhuriyet University Faculty of Pharmacy, Sivas / Turkey

${ }^{4}$ Department of Biochemistry, Cumhuriyet University Faculty of Pharmacy, Sivas / Turkey

${ }^{5}$ Department of Mathematics and Science Education, Kırıkkale University Faculty of Education, Klrıkkale / Turkey

${ }^{6}$ Department of Biotechnology, Faculty of Science, Bartin University, Bartin / Turkey

${ }^{7}$ Department of Chemistry, Ataturk University Faculty of Sciences, Erzurum / Turkey

\begin{abstract}
The current research aimed to determine and report in vitro antioxidant, antimicrobial, antibiofilm, cytotoxic, anti-cholinesterase, and anti-diabetic properties and the stability of the major component of basic oil of Thymbra spicata var. spicata through different phases as theoretically. Essential oil exhibits potential biological activities because of the multiple components it contains.In the current research, the evaluation of Thymbra spicata essential oil antioxidant properties was conducted utilizing 1,1-diphenyl-2-picrylhydrazyl (DPPH) and 2,2azinobis[3-ethylbenzthiazoline]-6-sulfonic acid (ABTS) radical scavenging activity.Antimicrobial activity was assessed from minimum inhibition concentration (MIC) using the technique of microdilution and cytotoxicity activity was evaluated by MTT assay through MCF-7 and PC3 human cancer cell lines.Consequently, Cytotoxic activity was evaluated by means of MTT assay utilized. The essential oil was detected to have $340 \mu \mathrm{g} / \mathrm{mL}$ inhibiting influence on the growth of PC3 prostate cancer cells with IC50 value. Also, the T. spicata plant was observed to significantly repress the enzymes, namely acetylcholinesterase (AChE), butyrylcholinesterase (BChE), $\alpha$-glycosidase. IC50 values of enzymes were obtained $0.23 \mu \mathrm{g} / \mathrm{mL}$ for $\mathrm{AChE}, 1.64 \mu \mathrm{g} / \mathrm{mL}$ for BChE, $7.78 \mu \mathrm{g} / \mathrm{mL}$ for $\alpha$-glycosidase. It was concluded that this plant may be used for Alzheimer's and diabetes disease.
\end{abstract}

\section{Article info}

History:

Received: 08.04.2021

Accepted: 07.09.2021

Keywords:

Thymbra spicata, Antioxidant activity, Antimicrobial activity, Cytotoxicity, Enzyme activity.

\section{Introduction}

Essential oil exhibits potential biological activities because of the multiple components it contains. Recently, the number of biological activity studies on volatile oils has increased rapidly, resulting in brilliant results. The interest in the use of essential oil as natural antioxidants are growing rapidly due to many essential oils has antioxidant properties [1].

The genus Thymbra L, (Lamicaceae), is known by Turkish local people as 'kekik or zahter'. It is not only important for its economic significance, but also important in commonly utilized in Turkish cuisine as edible ingredients of salad, condiment or herbal teas.
The genus is also important for its chemical constituents such as carvacrol and thymol as main components [2], exhibiting many biological activities [3]. Therefore, the leaves and essential oil of the genus uses for various purposes in flavoring, perfume, food and pharmaceutical industries.

T. spicata stands out with its significant medicinal effects in mainly Mediterranean countries where it is mostly used as in spice form and for purpose of preserving other food products [4]. Located within the Mediterranean and also in semi-arid climatic conditions, it mostly sprouts on calcareous soils located on hillsides with ample sunlight [5]. Also, the dried plant of $T$. spicata is used for curing asthma, colic, and bronchitis and coughs [6]. In this context, 
characterization of chemical composition and revealing of its biological activities is important to establish the basis for the uses of these plant raw materials and essential oil.

$\mathrm{AD}$ is characterized by neurofibrillary tangles and amyloid plaques. The AChEIs such as galanthamine, donepezil, rivastigmine, and tacrine are currently accessible as drugs for universal clinical therapy of $\mathrm{AD}$ [7]. In addition to red blood cells, synapses and neuromuscular connections in the brain generally contain cholinergic AChE in high concentrations [8]. Additionally, a non-special kind of ChE enzyme butyrylcholinesterase (BChE), commonly existing throughout the body, most significantly, in the blood, liver, the central nervous system and pancreas of humans, hydrolyzes various kinds of choline esters and [9]. BuChE has a common association with endothelial and glial cells in the brain [10].

Diabetes mellitus (DM) is a well-known metabolic disorder, which is characterized as an unusual postprandial enhance of blood glucose amount $[11,12]$. The control of postprandial hyperglycemia is known to be significant in the therapy of DM [13]. $\alpha$-Glycosidase exists in intestinal chorionic epithelium which is accountable for the depreciation of carbohydrates [14]. $\alpha$-Glycosidase inhibitors (AGIs) fall under the third class of oral hypoglycemic factors [15]. Diverse AGIs, such as voglibose and acarbose obtained from plant sources, can impressively control blood glucose amounts after food intake and thus in clinical use in the treatment of DM [16].

The present research aimed to characterize the basic oil contents and also to determine the biological activity such as antioxidant, antimicrobial, cytotoxicity, antidiabetic and anti-cholinesterase activity.

\section{Materials and Methods}

\subsection{Plant materials}

The plant content was purchased in a market in Hatay, Turkey, following it was identified by a plant specialist Dr. Mehmet Tekin of Trakya University, Faculty of Pharmacy, Department of Pharmaceutical Botany.

\subsection{Essential oil preparat}

In order to obtain the essential oil, flowers and leaves of $\mathrm{T}$. spicata were exposed to a hydrodistillation process through a Clevenger type apparatus for about 3 hours. The resulting oil yield accounted for $3.87 \%$.

\subsection{GC-MS analysis}

GS-MS analysis was conducted in the plant, drug and scientific research center of Anadolu University. Qualification of the essential oil was performed using an Agilent 5977B Mass Spectrometer coupled with an Agilent GC-7890B series (Agilent Technologies, USA). The GC was equipped with HP-Innowax capillary column $(60 \mathrm{~m} \times 250 \mu \mathrm{m} \times 0.25 \mu \mathrm{m}$ film thickness) with helium ( $\mathrm{He}$ ) utilized as the transport agent with $0.7 \mathrm{~mL} / \mathrm{min}$ rate of flow. GC oven temperature program was as follows: $60 \mathrm{oC}$ for $10 \mathrm{~min}$, up to $240 \mathrm{oC}$ at $1 \mathrm{oC} / \mathrm{min}$ and then kept at $220 \mathrm{oC}$ for 20 $\mathrm{min}$, a total of $80 \mathrm{~min}$. The injection temperature was $250 \mathrm{oC}$. In EI mode at $70 \mathrm{eV}$ of the mass spectrometer, $1 \mu \mathrm{L}$ of the oils were injected into the column. The components of the oil were detected through a comparison between relative retentive indices, mass spectra and pure original sample indices.

\subsection{Antioxidant activities}

\subsubsection{DPPH radical scavenging process}

DPPH assay is in wide use for assessment of antioxidant process due to the reliance of its mechanism on measuring hydrogen atom or electrondonating process. The assessment of (DPPH)free radical scavenging activity of the stable 1, 1diphenyl-2-picrylhydrazyl was conducted through the Sannigrahi approach [17]. Sample solution at different concentrations prepared in $80 \%$ methanol in a $1: 3$ volume to volume ratio in separate test tubes in triplicates was blended with $1 \mathrm{ml}$ of $0.1 \mathrm{mM}$ of DPPH in methanol. After 30 min standing in dark, decreased $\mathrm{DPPH} \cdot$ was determined as $517 \mathrm{~nm}$. Decreases in solution absorbance of DPPH resulted in increases in DPPH radical scavenging activity. Methanol with DPPH solution (without sample) functioned as a control. Through linear regression analysis of doseresponse curve plotting between \% inhibition and concentrations, 50\% (IC50 value) $\mathrm{DPPH} \bullet$ plant extracts scavenging processes were attained. The \% inhibition calculation is as the equation below:

$\%$ inhibition $=($ Absorbance of control-Absorbance of the sample) / Absorbance of control $\times 100$

\subsubsection{Decolorisation assay of ABTS radical cation}

As described previously, Re et. al., [18] method was utilized in the determination of ABTS free radical scavenging process [19]. Through $2.45 \mathrm{mM}$ potassium persulphate and $7 \mathrm{mM}$ aqueous ABTS stock solutions at a volume of 1:1 ratio, following ABTS radical cations production, the cations were left for incubation for attaining the reaction at $25^{\circ} \mathrm{C}$ for 16 hours in the dark. Dilution of the stock solutions with ethanol in order to give $0.70 \pm 0.02$ absorbance at $734 \mathrm{~nm}$ and equilibrated at $30^{\circ} \mathrm{C}$ yielded $\mathrm{ABTS} \cdot+$ working solution. Trolox, which is a vitamin $\mathrm{E}$ analog soluble in water, constituted the norm. At alternating concentrations as $0,50,100,150,200,250$, and 500 
$\mu \mathrm{M}$, a standard curve for calibration for Trolox is formed. In test tubes, $1 \mathrm{~mL}$ of each sample was mixed with radical cation solution, $1 \mathrm{~mL}$ of fresh ABTS+, and their absorbances are detected (at $734 \mathrm{~nm}$ ) following a 7 min incubation period in the environment in the absence of light.

\subsection{Antimicrobial activity}

The antimicrobial features of basic oil of T. spicata was determined by micro-well dilution assay according to standard procedures against 5 bacterial and fungal traits, namely as Grampositive (Staphylococcus aureus (ATCC 29213) and Enterococcus faecalis (ATCC 29212)), Gram-negative (Pseudomonas aeruginosa (ATCC 27853) and Escherichia coli (ATCC 25922)) and fungal trait (Candida albicans (ATCC 10231)). The essential oil was dissolved in $8 \%$ DMSO to prepared $20 \mathrm{mg} / \mathrm{ml}$ of stock solution. Serial two-fold dilutions of the essential oil stock were done with distilled water to provide final concentration between 5.0 and $0.02 \mathrm{mg} \mathrm{mL}-1$. Final size of inoculum was 5 $\mathrm{x} 105 \mathrm{CFU} / \mathrm{mL}$ at bacteria and $0.5-2.5 \times 103 \mathrm{CFU} / \mathrm{mL}$ at Candida in each well. The inoculated plates were incubated at $37{ }^{\circ} \mathrm{C}$ for bacteria and $35^{\circ} \mathrm{C}$ for Candida for a period of 16 to 24 hours under anaerobic conditions. Following, $10 \mu \mathrm{L}$ of a sterile $0.5 \%$ aqueous solution of 2, 3, 5-Triphenyltetrazolium chloride (TTC) (Merck, Germany) was mixed with each well to confirm microbial development. This experiment was performed in duplicate. The microplates were left to reincubate at $37^{\circ} \mathrm{C}$ for a period of 2 hours. Reducing the TTC by succinate dehydrogenase in viable cells led to the formation of formazan and the color changed from yellow to red, was determined as MIC value [20].

\subsection{Cytotoxicity assay}

Colorimetric MTT assay conducted in vitro cytotoxic activity of essential oil by using cell lines of two different cancers as human breast cancer MCF-7 and prostate cancer cell PC-3 lines [21]. The culture was carried out in $25 \mathrm{~cm} 2$ flasks in RPMI-1640 culture medium supplemented with $10 \%$ fetal bovine serum, $100 \mathrm{U} / \mathrm{mL}$ Penicillin, and $100 \mu \mathrm{g} / \mathrm{mL}$ Streptomycin in a humidified atmosphere including $5 \% \mathrm{CO} 2$, at $37^{\circ} \mathrm{C}$. Exponential growing was inoculated in 96-well microplates at a density of $5 \times 103$ cells per well in 100 $\mu \mathrm{L}$ of $10 \%$ FBS included the following trypsinization with $1 \mathrm{x}$ trypsin - EDTA and were allowed to $24 \mathrm{~h}$ of incubation before treatment. The essential oil concentrations in increasing amounts $(1-1000 \mu \mathrm{g} / \mathrm{mL})$ were then added in methanol. These cells were left to re-incubation for an additional $24 \mathrm{~h}$ with or without essential oil. Following this process, $10 \mu \mathrm{L}$ of MTT solution was mixed with the content of each well. After incubation for $4 \mathrm{~h}$, the color changes were determined at $570 \mathrm{~nm}$ using a microplate reader (Epoch, USA). These applications were conducted in triplicate. The essential oil cytotoxicity, IC50 value, was determined the concentration resulting in the inhibition of $50 \%$ of the cells.

\subsection{Determination of Apoptosis}

Such staining methods as acridine orange and ethidium bromide $(\mathrm{AO} / \mathrm{EB})$ were used for investigating the effects of essential oil on inducing apoptosis for cell lines of two different cancers like breast cancer MCF7 and prostate cancer PC-3. Cell lines were inoculated into 12 -well plate at a density of $2 \times 105$ cells/well in triplets and treated by T. spicata essential oil at a final concentration of $100 \mu \mathrm{g} / \mathrm{mL}$ in a growth medium without antibiotics for $24 \mathrm{~h}$. After incubation, each well was stained by $1 \mu \mathrm{g} / \mathrm{mL} \mathrm{AO} / \mathrm{EB}$ solution and the fluorescence intensities were screened by microscopy (Zeiss). Living cells clustered as green fluorescence and apoptotic cells clustered as red fluorescence.

\subsection{Enzyme inhibition activity}

\subsubsection{AChE/BChE inhibitory activity determination}

The determination of $T$. spicata inhibition efficacy on $\mathrm{AChE} / \mathrm{BChE}$ activities was conducted in line with the spectrophotometric procedure recommended by Ellman et. al., [22] as described previously [7]. In both reactions, the substrates utilized were acetylthiocholine iodide and butyrylthiocholine iodide (AChI/BChI) [23].

\subsection{Theoretical stability calculation of the major component}

In this study, theoretical calculations of the stability of Carvacrol, the major component of $\mathrm{T}$. spicata. var. spicata, were done in the ethanol, methanol and water phase. For the dielectric constant for ethanol, methanol and water dielectric EPS $=24.55,32.63$ and 78.39 values of the constants have been entered [24]. DFT procedure was used as the calculation method. 6-31G containing polarizing functions $(d, p)$ basis set was used $[25,26]$. The calculations are carried out in Gaussian 09W program [40] supported by Kırıkkale University.

\section{Results and Discussion}

\section{Theoretical results of component}

As can be seen from Fig 1., the oil of T. spicata. var. spicata was dominated by carvacrol $(63.4 \%)$, pcymene $(12.1 \%), \gamma$-terpinene $(11.9 \%)$ and thymol $(3.0 \%)$ as a major component. 


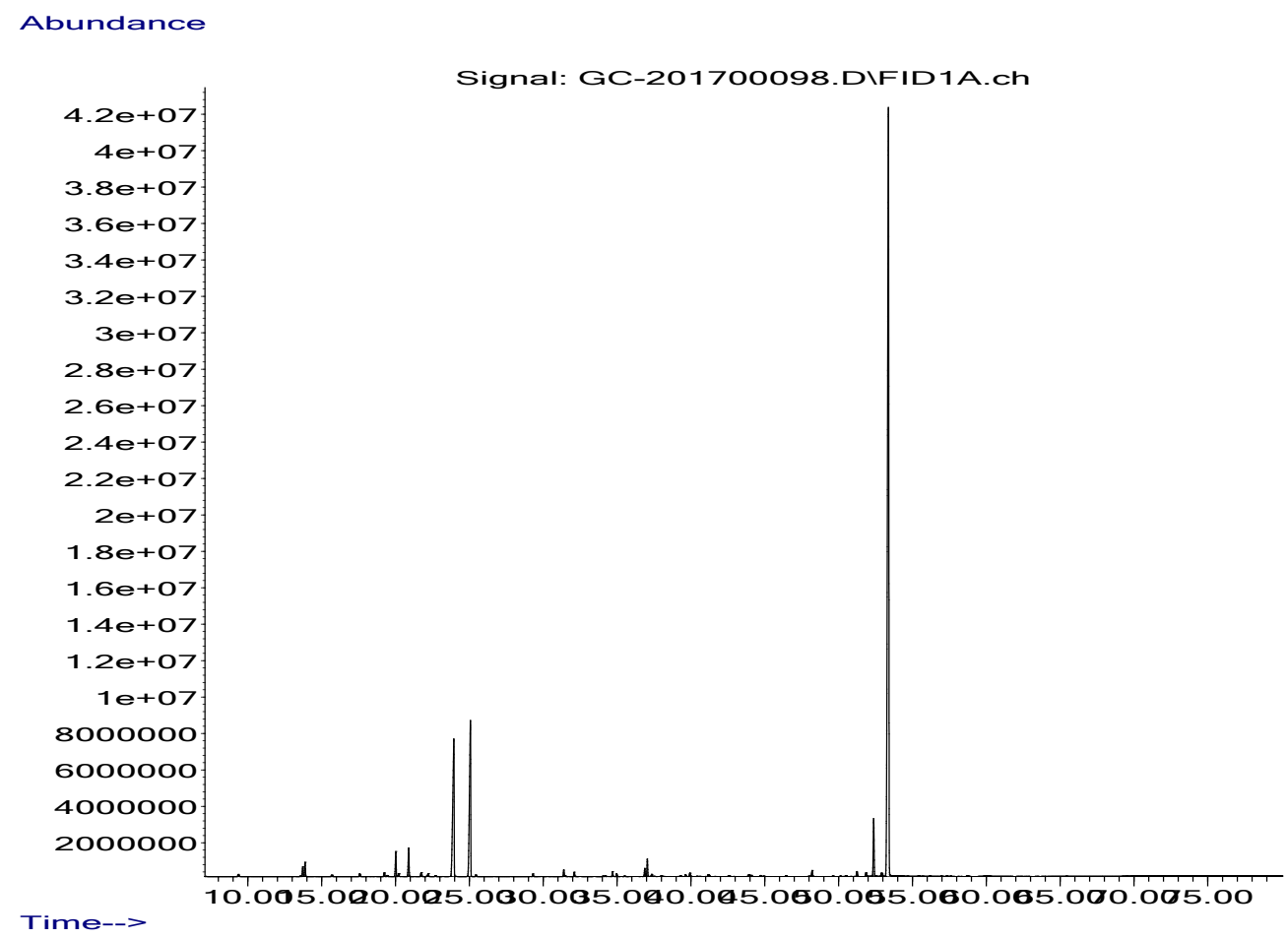

Figure 1. GC-MS chromatograme of T. spicata var. spicata essential oils

Carvacrol is the major component of T. spicata. var. density functional theory (DFT) in different phases is spicata and the theoretical calculation of it by using given in Table 1.

Table 1. Carvacro's values of $\Delta \mathrm{G}$, HOMO, LUMO, $\Delta$ (HOMO-LUMO) and Dipol Moment by using DFT

\begin{tabular}{cccccc}
\hline $\begin{array}{c}\text { Carvacrol in } \\
\text { different phases } \\
\begin{array}{c}\text { gas, ethanol, } \\
\text { methanol and } \\
\text { water })\end{array}\end{array}$ & $\begin{array}{c}\Delta \mathrm{G} \\
\text { Free Energy } \\
\text { (Hartree) }\end{array}$ & $\begin{array}{c}\text { HOMO } \\
(\mathrm{eV})\end{array}$ & $\begin{array}{c}\text { LUMO } \\
(\mathrm{eV})\end{array}$ & $\begin{array}{c}\Delta \text { (HOMO- } \\
\text { LUMO) } \\
(\mathrm{eV})\end{array}$ & $\begin{array}{c}\text { Dipole Moment } \\
\text { (Debye) }\end{array}$ \\
\hline Gas & -464.590955 & -0.22108 & -0.00907 & 0.21201 & 1.3559 \\
Ethanol & -464.597174 & -0.22538 & -0.01223 & 0.21315 & 1.8493 \\
Methanol & -464.597291 & -0.22550 & -0.01232 & 0.21318 & 1.8597 \\
Water & -464.597504 & -0.22572 & -0.01249 & 0.21323 & 1.8788 \\
\hline
\end{tabular}

According to data from Table1; Stability; (HOMOLUMO difference) Carvacrol in water $>$ Carvacrol in methanol $>$ Carvacrol in ethanol $>$ Carvacrol in gas

Polarity: (Dipol moment) Carvacrol in water > Carvacrol in methanol $>$ Carvacrol in ethanol $>$ Carvacrol in gas

Gibbs's free energy $(\Delta \mathrm{G})$ Carvacrol in water $>$ Carvacrol in methanol $>$ Carvacrol in ethanol $>$ Carvacrol in gas
Our theoretical results show that the stability of Carvacrol in water is more than the others phases and Carvacrol in water has a large dipole moment so it has a good resolution in water.

The 3D structures of the two target enzymes as AChE and $\mathrm{BChE}$ had been downloaded from the protein databank (PDB) and determined PDB id: 1ACL and 1POP, respectively $[27,28]$. (Table 2.) The inhibition effect of them on $\mathrm{AChE}$ and $\mathrm{BChE}$ related to $\mathrm{AD}$ was indicated by using the docking [40] program. 
Table 2. The inhibition of binding energy score of some active compounds on $\mathrm{AChE}$ and $\mathrm{BChE}$

\begin{tabular}{ccc}
\hline $\begin{array}{c}\text { Active compounds/Enzymes } \\
\text { (inhibition of binding energy score) }\end{array}$ & AChE (1ACL) & BChE (1POP) \\
\hline Carvacrol & -1145.75 & 362.31 \\
Tacrine & -893.15 & 179.30 \\
\hline
\end{tabular}

When we look at the table; We see that Carvacrol's AChE binding energy is relatively low compared to the Tacrine. As a result, AChE inhibiting effect is higher from Tacrine, which is the positive control group of the experimental study, therefore the docking scores define in which step the active substance in the plant we use in this inhibiting mechanism is more effective.

\section{Antioxidant activity}

Minimum one benzene ring with a hydroxyl functional group, which are usually called phenolic compounds, exists in the structure of the majority of natural molecules, especially those of plant origin. Due to the properties of donating hydrogen or single electron, this group usually has significant effects on the plant extracts or essential oils antioxidant activity [29]. In this study, the two most widely used antioxidant assays, DPPH and ABTS radical scavenging activity tests were employed for the assessment of antioxidant activity of essential oil from $T$. spicata. As can be inferred from antioxidant activity results and GC-MS analysis, the basic oil exhibited stronger activity in terms of free radical scavenging, which might be resulting from the higher amounts of phenolic components such as thymol and carvacrol (Figure 2 and 3).

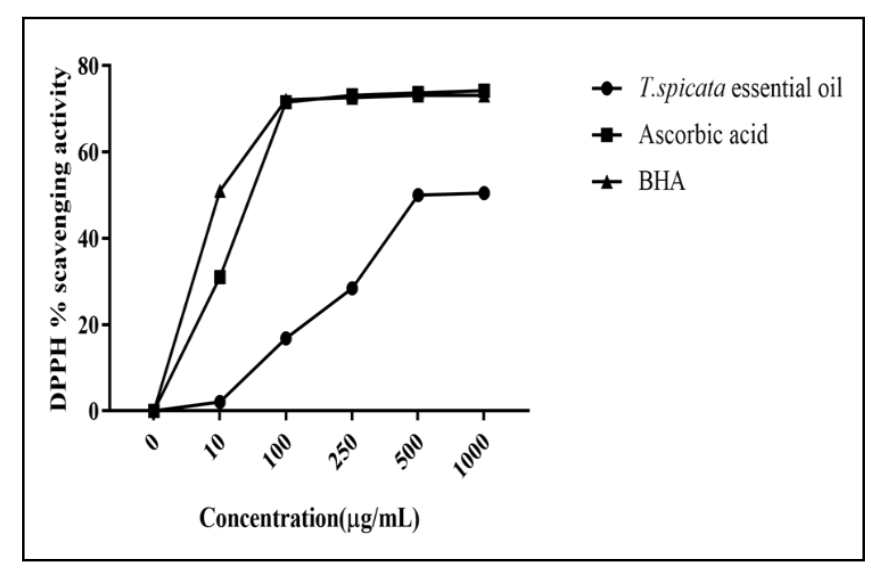

Figure 2. DPPH free radical scavenging activity of $T$. spicata var. spicata essential oil

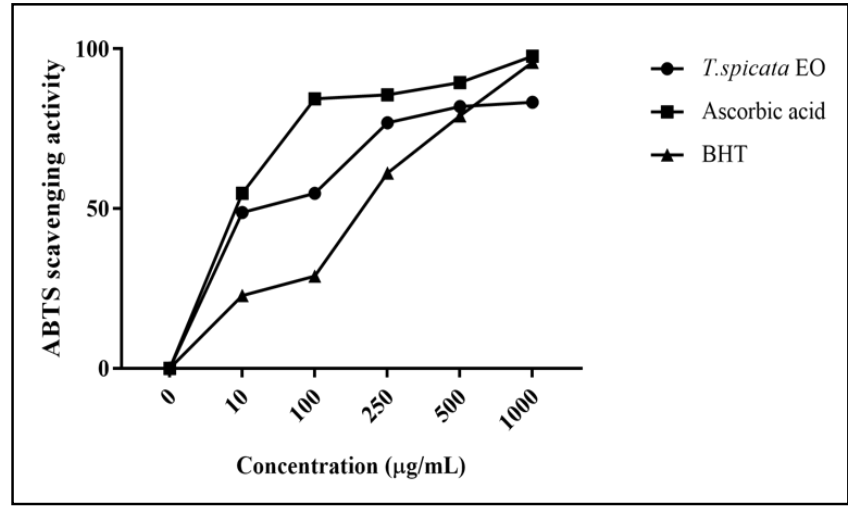

Figure 3. ABTS radical scavenging activity of $T$. spicata essential oil

Figure 3 demonstrated extract ABTS radical scavenging activity. Extract solubility and stereoselectivity of radicals were reported to have an effect on the extract's capacity in various test settings [30]. In the present study, ethanol extracts of T. spicata demonstrated potent scavenging activities for ABTS radicals. In comparison with DPPH, the extract, even in lower concentrations, has yielded potent ABTS radical scavenging activity. This high potential of the extract is likely to be resulting from its polar constituent known to be more potent in comparison to DPPH in yielding radical scavenging activity for ABTS, which might result from the water-soluble characteristics of ABTS; whereas DPPH does not have this trait [31].

\section{Antimicrobial activity}

Broth microdilution assay was utilized as the medium detecting MIC values of the essential of $T$. spicata. Essential oil demonstrated various antimicrobial activity with microorganisms tested in the study (Table $3)$. 
Table 3. Minimum inhibitory concentrations of essential oil obtained from T. spicata herbs

\begin{tabular}{llc}
\hline & Essential oil of $T$. spicata L. var. & $\mathrm{mg} / \mathrm{mL}$ \\
\hline S/No. & Microorganisms & \\
\hline 1 & E. coli & 1.25 \\
\hline 2 & S. aureus & 1.25 \\
\hline 3 & P. aeruginosa & 5.0 \\
\hline 4 & E. faecalis & 5.0 \\
\hline 5 & C. albicans & 1.25 \\
\hline
\end{tabular}

$1.25-5.0 \mathrm{mg} / \mathrm{mL}$ was determined as the range of the extracts MIC values. According to the results, E. faecalis and $P$. aeruginosa were less affected by the essential oil of $T$. spicata than other microorganisms with the lowest MIC values $5.0 \mathrm{mg} / \mathrm{mL}$, while the MIC value against other microorganisms is $1.25 \mathrm{mg} / \mathrm{mL}$.

\section{Cytotoxicity assay}

3-(4, 5-dimethylthiazol-2-yl)-2,5-diphenyltetrazolium bromide (MTT) assay was the medium of evaluation of essential oil proliferative effect on cellular development. The transition of tetrazolium bromide (MTT) from yellow to purple formazan through mitochondrial enzyme succinate dehydrogenase activity in viable cells constitutes colorimetric assay. The findings clearly demonstrate that for MCF-7 cancer cells, PC-3 cancer cells, basic oil possesses a significant antiproliferative activity, with $\mathrm{IC}_{50}$ of 88.63 $\mu \mathrm{g} / \mathrm{mL}$ and with $\mathrm{IC}_{50}$ of $79.25 \mu \mathrm{g} / \mathrm{mL}$, respectively.

\section{Enzymes inhibitory activity}

The utilizing these plant origin materials as supplementary medicines in dementia treatment, shows variations in line with the expectations of that specific society ("Alzheimer's Association). In comparison to the ones in the Far East countries such as China with the exception of the limited number of plants like Ginkgo biloba, whose major contents, the ginkgolides, are shown to have neuroprotective, antioxidant, and cholinergic activities related to $\mathrm{AD}$ mechanisms, in traditional Western medicine, memory enhancing plants or pharmacological properties of traditional cognitive have not been extensively evaluated in the context of prevalent models of $\mathrm{AD}$ [32]. Placebo-controlled clinical trials reported similar therapeutic effects of Ginkgo biloba extracts in AD currently prescribed drugs such as donepezil or tacrine and, importantly, undesirable side effects of Ginkgo biloba are minimal [33].

In the Alzheimer's -afflicted brain, the cells that utilize $\mathrm{ACh}$ are destroyed or harmed, leading to lower amounts of the chemical messenger $[34,35]$. A ChEI is designed to reduce $\mathrm{AChE}$ activity, thereby slowing $\mathrm{ACh}$ separation. By memorizing levels of $\mathrm{ACh}$, the drug can help compensate for the detriment of functioning brain cells. In the present study, T. spicata plant efficiently managed to inhibit $\mathrm{AChE}, \mathrm{BChE}$, and $\alpha$-glycosidase enzymes (Table 4 ).

Table 4. The enzyme inhibition results of essential oil of Thymbra spicata L. var. spicata against AChE, BChE, and $\alpha$-glycosidase enzymes.

\begin{tabular}{ccccccc}
\hline \multirow{2}{*}{$\begin{array}{c}\text { Extract or Reference } \\
\text { Compounds }\end{array}$} & \multicolumn{2}{c}{$\alpha$-glycosidase } & \multicolumn{3}{c}{ AChE } & \multicolumn{2}{c}{$\mathrm{BChE}$} \\
\cline { 2 - 7 } & $\mathrm{IC}_{50}(\mu \mathrm{g} / \mathrm{mL})$ & $\mathrm{R}^{2}$ & $\mathrm{IC}_{50}(\mu \mathrm{g} / \mathrm{mL})$ & $\mathrm{R}^{2}$ & $\mathrm{IC}_{50}(\mu \mathrm{g} / \mathrm{mL})$ & $\mathrm{R}^{2}$ \\
\hline Thymbra spicata $\mathrm{L}$ & 7.78 & 0.971 & 0.23 & 0.992 & 1.64 & 0.989 \\
Tacrine* & - & - & 12.36 & 0.958 & 19.11 & 0.981 \\
Acarbose** & 22.8 & - & - & - & - & - \\
\hline
\end{tabular}

\footnotetext{
*Tacrine was used as positive control for $\mathrm{AChE}$ and $\mathrm{BChE}$ enzymes and determined as $\mu \mathrm{M}$ levels.

**Acarbose was used as positive control for $\alpha$-amylase and $\alpha$-glycosidase enzymes and determined as $\mu \mathrm{M}$ levels, which given in references (Noh et al., 2011).
} 
TAC (9-amino-1, 2, 3, 4-tetrahydroacridine), the initial drug to be legally accepted for placative treatment in $\mathrm{AD}$, acts as an agent reversibly inhibiting $\mathrm{BChE}$ and AChE. These enzymes $\mathrm{IC}_{50}$ values were obtained 0.23 $\mu \mathrm{g} / \mathrm{mL}$ for AChE, $1.64 \mu \mathrm{g} / \mathrm{mL}$ for BChE, $7.78 \mu \mathrm{g} / \mathrm{mL}$. Moreover, Tacrine (TAC), utilized as BChE and AChE inhibition positive standard, yielded $\mathrm{IC}_{50}$ values 19.11 $\mu \mathrm{mol} / \mathrm{L}$ and $12.36 \mu \mathrm{mol} / \mathrm{L}$, respectively. In terms of their safety requirements and therapeutic implications, edible plant materials in food supplement form and various herbs of natural origin which are in use as medicinal agents in medicine have witnessed an accumulating surge of scientific interest in the treatment of diabetic disease. Considering the fact that the majority of the drugs provided by modern Western medicine on the counters are, to a certain extent, obtained from plant materials, this trend is far from being scientifically predicted [36].

Natural $\alpha$-amylase and $\alpha$-glucosidase inhibitors are being evaluated as novel candidates to control hyperglycemia in diabetic patients [37]. For instance, the traditional Arabic medicine is still determined and may create efficient novel compounds for treating diabetes disease and other diseases, as the 69 plant species that are introduced in a review about diabetes treatment in Jordan [38]. Some of these plants have been shown to inhibit glucosidase and amylase activities in vivo and in vitro, including Varthemia iphionoides, Geranium graveolens, Sarcopoterium spinosum, Pistacia atlantica, and Rheum ribes [39].

The interactions of active ingredients in $\mathrm{T}$. spicata essential oil with cancer cells are given in Figures 4, 5, 6 and 7.

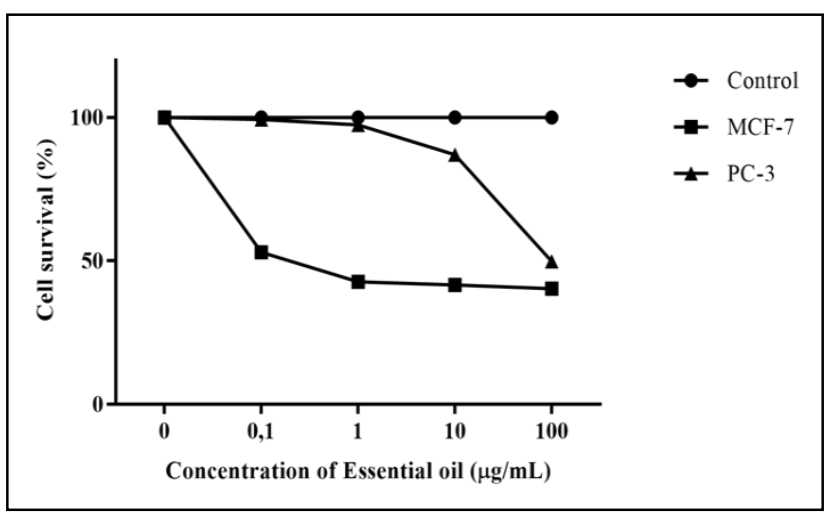

Figure 4. Cell proliferation assay of MCF-7 and PC-3 cell lines in the presence of the essential oil of $T$. spicata with different concentrations for $24 \mathrm{~h}$.

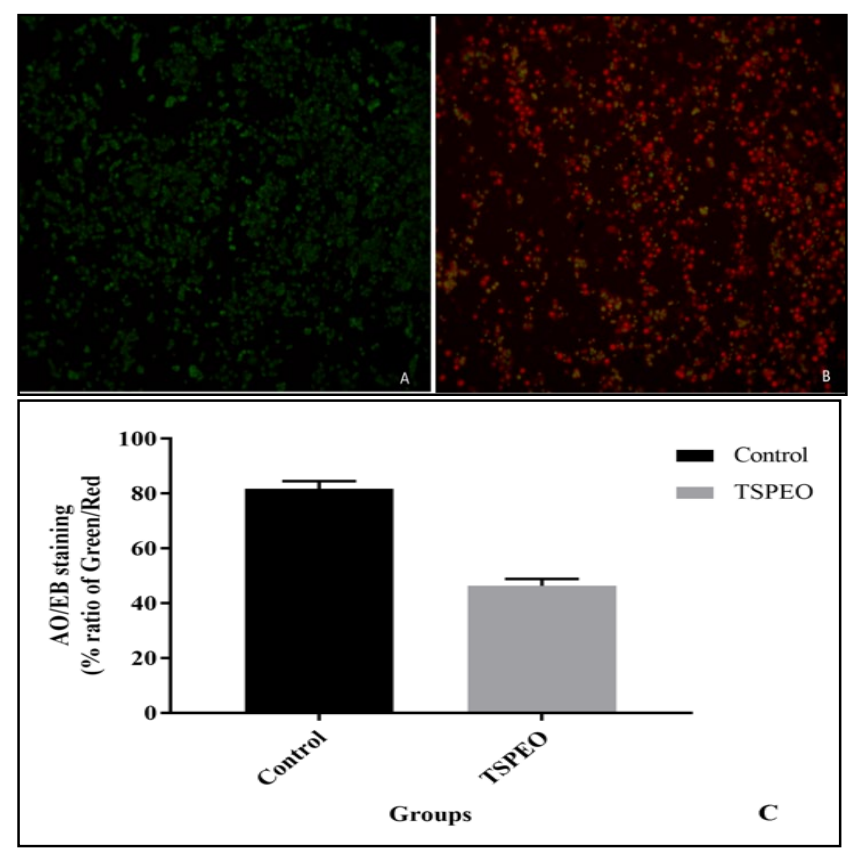

Figure 5. AO/EB staining of MCF-7 cancer cell lines with the concentration of $100 \mu \mathrm{g} / \mathrm{mL}$ for the incubation period of 24h. A: Fluorescence images of control MCF-7 cells; B: Fluorescence images of treated MCF-7 cells with $T$. spicata essential oil after staining, $\mathrm{C}$ : ratios of $\mathrm{AO} / \mathrm{EB}$ staining in MCF-7 cell line at $100 \mu \mathrm{g} / \mathrm{mL}$ concentrations of T. spicata essential oil for $24 \mathrm{~h}$.
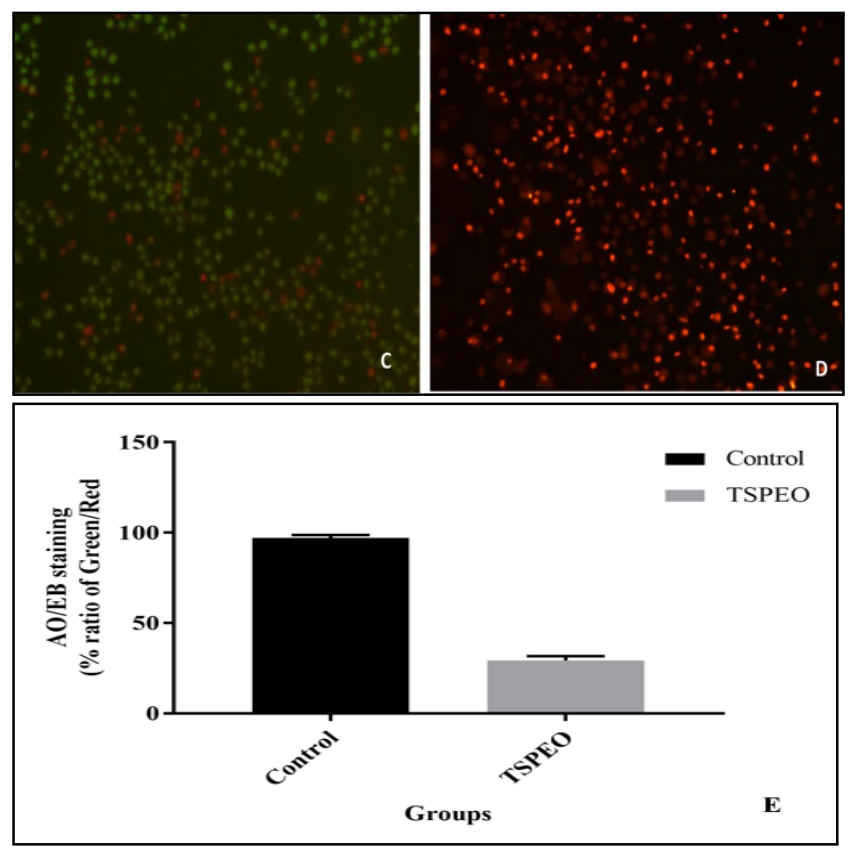

Figure 6. AO/EB staining of $\mathrm{PC}-3$ cancer cell lines with the concentration of $100 \mu \mathrm{g} / \mathrm{mL}$ for the incubation period of $24 \mathrm{~h}$. C: Fluorescence images of control PC-3 cells; D: Fluorescence images of treated PC-3 cells with T. spicata essential oil after staining; $\mathrm{E}$ : ratios of $\mathrm{AO} / \mathrm{EB}$ staining in PC-3 cell line at $100 \mu \mathrm{g} / \mathrm{mL}$ concentrations of $T$. spicata essential oil for $24 \mathrm{~h}$. 


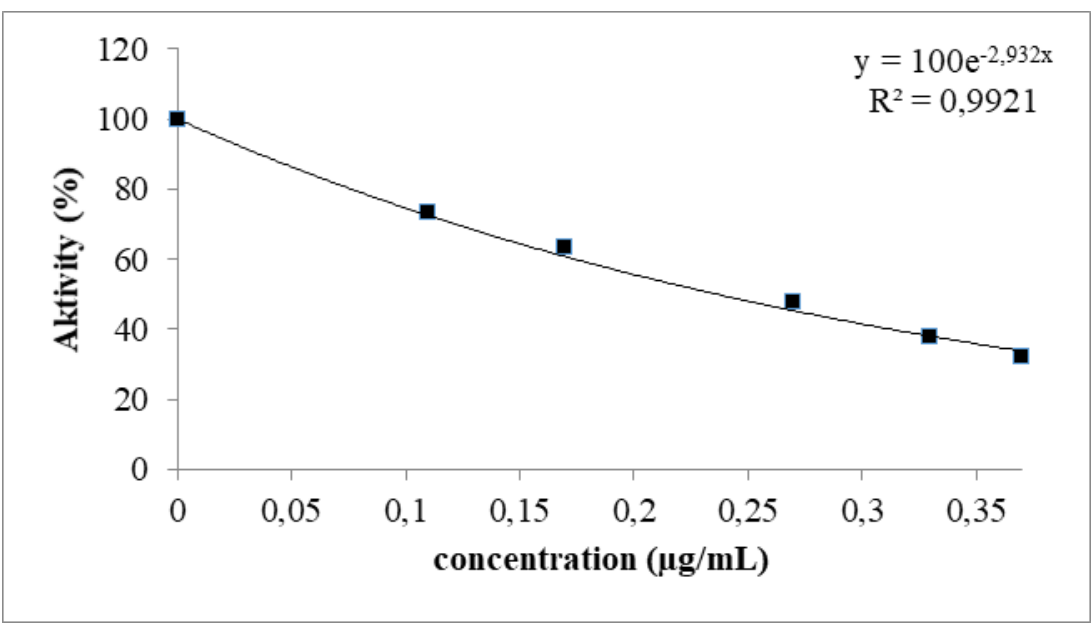

A

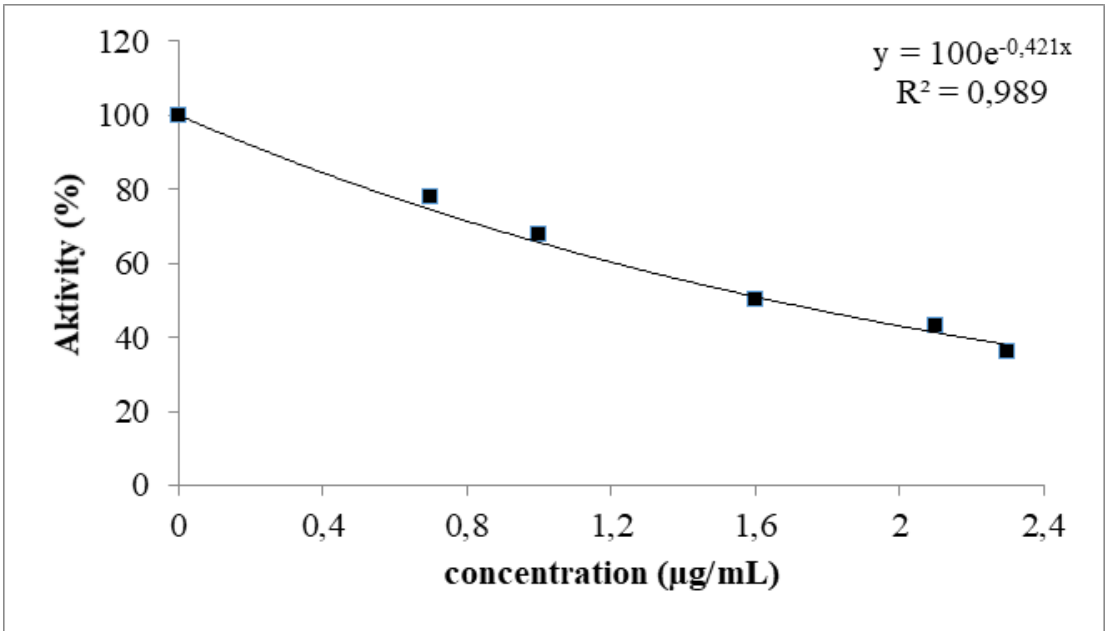

B

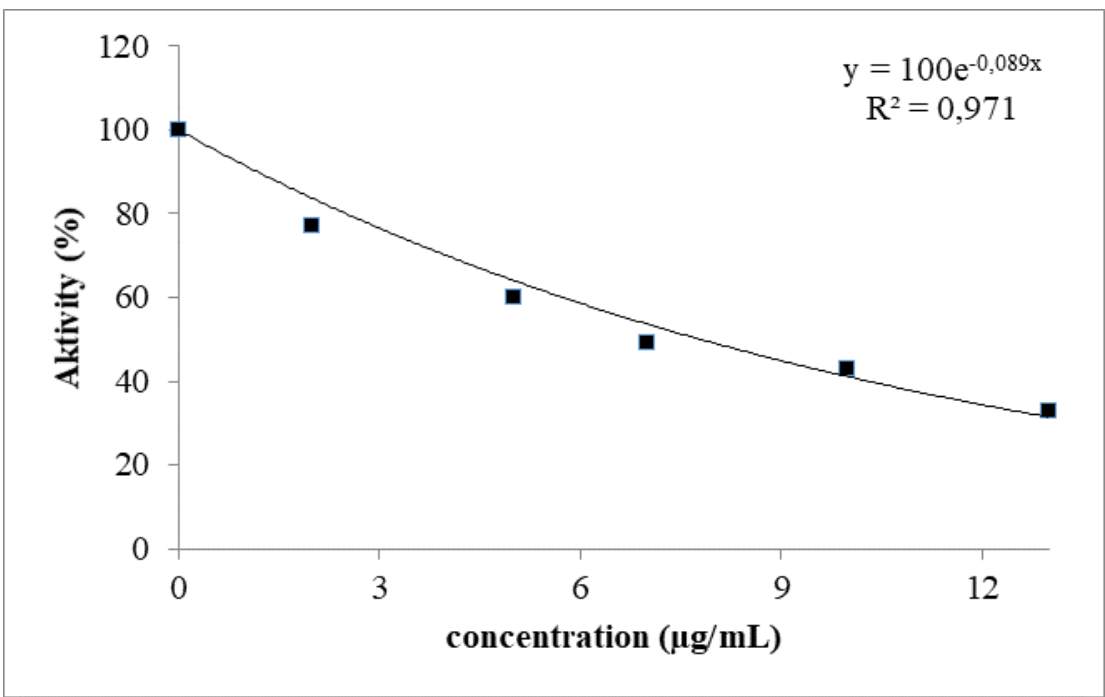

C

Figure 7. The $\mathrm{IC}_{50}$ graphs of Thymbra spicata L. var. spicata essential oil against A) AChE, B) BChE, C) $\alpha-$ glycosidase enzymes. 


\section{Conclusion}

The current research demonstrates that the essential oil of $T$. spicata is a good source of potent and natural antioxidants as well as a good $\alpha$ glycosidase, BChE, and AChE inhibitors. The activities mentioned above may have a relation with high levels of phenolic content existing within such essential oil. The plant materials have demonstrated a satisfactory inhibitory effect on the enzymes mentioned above. AChE, BChE inhibition has significant potential not only in the development of drugs but also in other fields such as toxicology and medicine. Moreover, the main component of $T$. spicata, Carvacrol, in water has low chemical reactivity and high kinetic stability. On the other hand, this plant can be a drug candidate as antidiabetic, anticholinergic and food additive.

\section{Conflicts of Interest}

The study has been performed in accordance with ethical standards.All authors read and approved the manuscript. The authors have no conflict of interest. All authors read and approved the manuscript. The research has not human participants and/or animals.

\section{References}

[1] Chaieb K., Zmantar T., Ksouri R., Hajlaoui H., Mahdouani K., Abdelly C., Bakhrouf A., Antioxidant properties of the essential oil of Eugenia caryophyllata and its antifungal activity against a large number of clinical Candida species, Mycoses, 50(5) (2007) 403406.

[2] Kokkini S.V.D., Carvacrol-rich plants in Greece, J. Flavour Fragr.,4 (1989) 1-7.

[3] Juven B. J., Kanner J., Schved F., Weisslowicz H., Factors that interact with the antibacterial action of thyme essential oil and its active constituents, J. Appl. Bacteriol, 76 (1994) 626-631.

[4] Kızıl S., Toncer O., Diraz E., Variation of agronomical characteristics and essential oil components of zahter (Thymbra spicata L. var. spicata) populations in semi-arid climatic conditions, Turkish J. F. Crop., 20 (2015)
$242-251$

[5] Kiz1l S., Determination of essential oil variations of Thymbra spicata var. spicata L. naturally growing in the wild flora of East Mediterranean and Southeastern Anatolia regions of Turkey, Ind. Crops Prod., 32 (2010) 593-600.

[6] İnan M, Kirpık M, Kaya DA, K.S., Effect of harvest time on essential oil composition of Thymbra spicata L. growing in flora of Adiyaman, Advenced Environ. Biol, 5 (2011) 356-358.

[7] Bayrak C, Taslimi P, Gulcin İ, M.A., The first synthesis of 4-phenylbutenone derivative bromophenols including natural products and their inhibition profiles for carbonic anhydrase, acetylcholinesterase and butyrylcholinesterase enzymes, Bioorg Chem.,72 (2017) 359-366.

[8] Caglayan C., Demir Y., Kucukler S., Taslimi P., Kandemir F.M., Gulçin I., The effects of hesperidin on sodium arsenite-induced different organ toxicity in rats on metabolic enzymes as antidiabetic and anticholinergics potentials: A biochemical approach, J. Food Biochem., 43(2) (2019b ) e12720.

[9] Kocyigit U.M., Taşkıran A.Ş., Taslimi P., Yokuş A., Temel Y., Gulcin İ., Inhibitory effects of oxytocin and oxytocin receptor antagonist atosiban on the activities of carbonic anhydrase and acetylcholinesterase enzymes in the liver and kidney tissues of rats, J. Biochem. Mol. Toxicol, (2017b) e21972.

[10] Gul H.I. A., Demirtas G., Ucar P.T., Gulcin İ, Synthesis of Mannich bases by two different methods and evaluation of their acetylcholine esterase and carbonic anhydrase inhibitory activities, Lett. Drug Des. Discov.,14(10) (2016) 573-580.

[11] Taslimi P., Aslan H.E., Demir Y., Oztaskin N., Maraş A., Gulçin İ., Beydemir S., Goksu S., Diarylmethanon, bromophenol and diarylmethane compounds: Discovery of potent aldose reductase, $\alpha$-amylase and $\alpha$ glycosidase inhibitors as new therapeutic approach in diabetes and functional 
hyperglycemia, Int. J. Biol. Macromol.,119 (2018) 857-863.

[12] Demir Y., Taslimi P., Ozaslan M.S., Oztaskin N., Çetinkaya Y., Gulçin İ., Beydemir Ş., Goksu S., Antidiabetic potential: In vitro inhibition effects of bromophenol and diarylmethanones derivatives on metabolic enzymes, Arch. Pharm. (Weinheim), 351(12) (2018) e1800263.

[13]Demir Y., Özaslan M.S., Duran H.E.., Küfrevioğlu Ö.İ., Beydemir Ş., Inhibition effects of quinones on aldose reductase: Antidiabetic properties, Environ. Toxicol Pharmacol, 70 (2019) 103195.

[14]Demir Y., Durmaz L., Taslimi P., Gulçin İ., Antidiabetic properties of dietary phenolic compounds: Inhibition effects on $\alpha$-amylase, aldose reductase, and $\alpha$-glycosidase, Biotechnol. Appl. Biochem., 66(5) (2019) 781-786.

[15]Demir Y.., Duran H.E., Durmaz L., Taslimi P., Beydemir Ş., Gulçin İ., The Influence of Some Nonsteroidal Anti-inflammatory Drugs on Metabolic Enzymes of Aldose Reductase, Sorbitol Dehydrogenase, and $\alpha$-Glycosidase: a Perspective for Metabolic Disorders, Appl. Biochem. Biotechnol.,190(2) (2020) 437-447.

[16]Kang W., Song Y., Gu X., $\alpha$-glucosidase inhibitory in vitro and antidiabetic activity in vivo of Osmanthus fragrans, J. Med. Plants Res., 6 (2012) 2850-2856.

[17] Sannigrahi S., Mazuder U.K., Pal D.K., Parida S., Jain S., Antioxidant potential of crude extract and different fractions of Enhydra fluctuans Lour, Iran. J. Pharm. Res.,9 (2010) 75-82.

[18] Re R., Pellegrini N., Proteggente A., Pannalaa A., MinYang, Rice-Evans C., Rice-Evans, Antioxidant activity applying an improved ABTS radical cation decolorization assay, Free Radic. Biol. Med.,26 (1999) 1231-1237.

[19] Topal F., Topal M., Gocer H., Kalın P., Kocyigit U.M., Gulcin İ., Alwasel S.H., Antioxidant activity of taxifolin: An activitystructure relationship, Journal of Enzyme Inhibition and Medicinal Chemistry, 31(4) (2016) 674-683.
[20] Tao Y., Zhang Y., Cheng Y., Wang Y., Rapid screening and identification of $\alpha$-glucosidase inhibitors from mulberry leaves using enzyme-immobilized magnetic beads coupled with HPLC/MS and NMR, Biomed. Chromatogr., 27 (2013) 148-155.

[21] Trojan-Rodrigues M., Alves T.L.S., Soares G.L.G., Ritter M.R., Plants used as antidiabetics in popular medicine in Rio Grande do Sul, southern, Brazil, $J$. Ethnopharmacol, 139 (2012) 155-163.

[22] Athar M., Back J.H., Tang X., Kim K.H., Kopelovich L., Bickers D.R., Kim A.L., . Resveratrol: A review of preclinical studies for human cancer prevention, Toxicol. Appl. Pharmacol., 224 (2007) 274-283.

[23] Noh J.S., Park C.H., Yokozawa T., Treatment with oligonol, a low-molecular polyphenol derived from lychee fruit, attenuates diabetesinduced hepatic damage through regulation of oxidative stress and lipid metabolism, $B r . J$. Nutr., 106 (2011) 1013-1022.

[24] Varmaghan Z., Monajjemi M., Mollaamin F. $\mathrm{Ab}$ Initio Study of Vinblastine- Tubulin Anticancer Complex, Biomacromolecular Journal, 1(1) (2015) 46- 51.

[25] Gökalp F., The chemical activity of Juglone in different phases as a protective agent, Journal of Fluorine Chemistry, 42 (2021)109701.

[26] Gökalp F., An investigation of the olive phenols activity as a natural medicine, Journal of Food and Drug Analysis, 26(2) (2018) 657-661.

[27] Ritchie D.W., Recent progress and future directions in protein-protein docking, Curr. Protein Pept. Sci., 9(1) (2008) 1-15.

[28] Ahmad H., Ahmad S., Shah S.A.A., Latif A., Ali M., Khan F.A., Tahir M.N., Shaheen F., Wadood A., Ahmad M., Antioxidant and anticholinesterase potential of diterpenoid alkaloids from Aconitum heterophyllum, Bioorg. Med. Chem., 25(13) (2017) 33683376.

[29] Gülçin İ., Antioxidant activity of eugenol: a structure-activity relationship study, J. Med. 
Food, 14(9) (2011)975-85.

[30] Yu L., Haley S., Perret J., Harris M., Wilson J., Qian M., Free radical scavenging properties of wheat extracts, J. Agric. Food Chem., 50 (2002)1619-1624.

[31]Gulcin İ., Antioxidant activity of food constituents-An overview, Archives of Toxicology, 86(3) (2012) 345-391.

[32]Herring A., Ambrée O., Tomm M., Habermann H., Sachser N., Paulus W., Keyvani K., Environmental enrichment enhances cellular plasticity in transgenic mice with Alzheimer-like pathology, Exp. Neurol., 216 (2009) 184-192.

[33] Francis P.T., Palmer A.M., Snape M., Wilcock G.K., The cholinergic hypothesis of Alzheimer' s disease: a review of progress, $J$. Neurol. Neurosurg Psychiatry, 66 (1999) 137-147.

[34] Kocyigit U.M., Budak Y., Gurdere M.B., Erturk F., Yencilek B., Taslimi P., Gulcin İ., Ceylan M., Synthesis of chalcone-imide derivatives and investigation of their anticancer and antimicrobial activities, carbonic anhydrase and acetylcholinesterase enzymes inhibition profiles. Arch. Physiol, Biochem., (2017) 3455.

[35] Kocyigit U.M., Taslimi P., Gezegen H., Gulcin I., Ceylan M., Evaluation of acetylcholinesterase and carbonic anhydrase inhibition profiles of $1,2,3,4,6-$ pentasubstituted-4-hydroxy-cyclohexanes, $J$. Biochem. Mol. Toxicol, 31(9) (2017) 21938

[36] Sy G.Y., Cissé A., Nongonierma R.B., Sarr M., Mbodj N.A., Faye B., Hypoglycaemic and antidiabetic activity of acetonic extract of Vernonia colorata leaves in normoglycaemic and alloxan-induced diabetic rats, $J$.
Ethnopharmacol., 98 (2005) 171-175.

[37] Jung M., Park M., Lee H.C., Kang Y.H., Kang E.S., Antidiabetic agents from medicinal plants, Curr. Med. Chem., 13 (2006) 12031218.

[38] Malviya N., Jain S., Malviya S., Antidiabetic potential of medicinal plants, Acta Pol. Pharm. - Drug Res., 67 (2010) 113-118.

[39] Grover J.K., Yadav S., Vats V., Medicinal plants of India with anti-diabetic potential, $J$. Ethnopharmacol., 81 (2002) 81-100.

[40]Frisch M.J., Trucks G.W., Schlegel H.B., Scuseria G.E., Robb M.A., Cheeseman J.R., G. Scalmani, V. Barone, B. Mennucci, G.A. Petersson, H. Nakatsuji, M. Caricato, X. Li, H.P. Hratchian, A.F. Izmaylov, J. Bloino, G. Zheng, J.L. Sonnenberg, M. Hada, M. Ehara, K. Toyota, R. Fukuda, J. Hasegawa, M. Ishida, T. Nakajima, Y. Honda, O. Kitao, H. Nakai, T. Vreven, J.A. Montgomery Jr., J.E. Peralta, F. Ogliaro, M. Bearpark, J.J. Heyd, E. Brothers, K.N. Kudin, V.N. Staroverov, R. Kobayashi, J. Normand, K. Raghavachari, A. Rendell, J.C. Burant, S.S. Iyengar, J. Tomasi, M. Cossi, N. Rega, J. M. Millam, M. Klene, J.E. Knox, J.B. Cross, V. Bakken, C. Adamo, J. Jaramillo, R. Gomperts, R.E. Stratmann, O. Yazyev, A.J. Austin, R. Cammi, C. Pomelli, J.W. Ochterski, R.L. Martin, K. Morokuma, V.G. Zakrzewski, G.A. Voth, P. Salvador, J.J. Dannenberg, S. Dapprich, A.D. Daniels, O. Farkas, J.B. Foresman, J.V. Ortiz, J. Cioslowski, D.J. Fox, Gaussian, Inc., Wallingford CT, (2009). 